URSZULA PULIŃSKA

Uniwersytet Warmińsko-Mazurski

w Olsztynie

\title{
NADZÓR IDEOLOGICZNY ORGANÓW PARTYJNYCH NAD NAUCZYCIELAMI NA WARMII I MAZURACH W LATACH 1945-1948
}

\begin{abstract}
Pulińska Urszula, Nadzór ideologiczny organów partyjnych nad nauczycielami na Warmii i Mazurach w latach 1945-1948 [Ideological Aspect of Supervising Teachers Between 1945 and 1948 in the Region of Warmia and Mazury]. Studia Edukacyjne nr 32, 2014, Poznań 2014, pp. 321-341. Adam Mickiewicz University Press. ISBN 978-83-232-2837-0. ISSN 1233-6688

After the Second World War two types of pedagogical supervision were de facto present in Poland. First, supervising as a result of regulations and laws, administrated by the Ministry of Education and its regional departments; the other one, existing among Polish Social Democrats structures, was the sector of Educational Departments. That was the case of party supervision at the central and regional level. Party bodies supervised, controlled and influenced education and a number of people associated with parties of the so-called Democratic Camp were members of school administration, the Association of Polish Teachers and pedagogical supervision structures. This activity determined the framework and development of education in Warmia and Mazury region in the following years.
\end{abstract}

Key words: supervising, ideology, teachers, control, education

Określenie „nadzór" użyte w tytule odnosi się do pojęcia nadzoru pedagogicznego tylko $\mathrm{w}$ zakresie kwestii związanych z kontrolą i możliwością sprawowania władztwa przez organy partyjne wobec pracowników oświaty. Oznacza w przedstawianym kontekście raczej potoczne rozumienie tego słowa, jako kontrolowanie lub pilnowanie czegoś lub kogoś, a także jako komórkę organizacyjną jakiejś instytucji, w tym wypadku partii politycznej, która kogoś lub coś nadzoruje lub kontroluje. Oznacza również personel nadzorujący i jego działania kontrolne, ale także władcze i represyjne.

Poprzez organa partyjne należy rozumieć wszystkie komórki organizacyjne Polskiej Partii Robotniczej (PPR) i Polskiej Zjednoczonej Partii Robot- 
niczej (PZPR), które działały, nadzorowały, kontrolowały i wpływały na oświatę, $\mathrm{w}$ tym przede wszystkim na nauczyciela $\mathrm{w}$ latach powojennych na Warmii i Mazurach. W powojennej Polsce mamy bowiem do czynienia z dwoma rodzajami nadzoru nad oświatą. Pierwszym był umocowany $\mathrm{w}$ przepisach, ustawach, czy rozporządzeniach nadzór sprawowany przez Ministerstwo Oświaty i podlegle mu Kuratoria Okręgowe, drugim zaś był funkcjonujący w strukturach partyjnych PPR pion Wydziałów Oświatowych. Istniał on zarówno na poziomie Komitetu Centralnego (KC) PPR, jak i w terenowych Komitetach Wojewódzkich (KW) tej partii.

Początkowo władze PPR nie widziały potrzeby tworzenia oddzielnych komórek, zarówno na szczeblu centralnym, jak i wojewódzkim, zajmujących się w szczególności oświatą. Miały one bowiem całkowity wpływ na poczynania władz oświatowych poprzez swoich członków zasiadających we władzach oświatowych na szczeblu centralnym. Ministrem Oświaty od lipca 1944 r. był Stanisław Skrzeszewski, zaś jego zastępcą Władysław Bieńkowski. Wśród dyrektorów najważniejszych departamentów byli również członkowie PPR, jak: Żanna Kormanowa, Eustachy Kuroczko, czy Stanisław Arnold. Poza tym, trzech innych działaczy tej partii zajmowało stanowiska naczelników Wydziałów. Taki stan rzeczy trwał do 28 czerwca 1945 r., kiedy to w ramach umowy o tworzeniu Tymczasowego Rządu Jedności Narodowej, ministrem oświaty został Czesław Wycech z PSL-u. Osłabiło to zdecydowanie wpływy PPR-u w ministerstwie, chociaż nie do końca je wyeliminowało. Jak pisze J. Jakubowski, ten stan rzeczy przyczynił się do powstania partyjnego pionu oświatowego, który budowano poczynając od władz centralnych $(\mathrm{KC})$, a skończywszy na jednostkach terenowych w województwach $(\mathrm{KW})^{1}$. Jak pisze Witold Chmielewski, w owym czasie

decyzyjne centrum oddziaływania ideowopolitycznego i społecznego PPR na środowisko oświatowe przesunęło się z Ministerstwa Oświaty do odpowiednich struktur społecznych, a następnie etatowych Komitetu Centralnego oraz komitetów wojewódzkich, powiatowych i miejskich².

PPR już w maju $1945 \mathrm{r}$. podejmowało próby rozszerzenia swoich wpływów w środowisku nauczycielskim czy szerzej - oświatowym. Służyły temu narady aktywu partyjnego. Na pierwszej z nich, która odbyła się 13-14 maja 1945 r., podjęto próbę określenia, jakie kierunki działania wybrać i jakie obszary oraz zagadnienia powinny stanowić priorytet $\mathrm{w}$ działalności partii

1 J. Jakubowski, Polityka oświatowa Polskiej Partii Robotniczej 1944-1948, Warszawa 1975, s. $138-140$.

2 W. Chmielewski, Ksztatcenie nauczycieli w okresie ideologizacji szkolnictwa (1944-1956), Warszawa 2006, s. 25-26. 
wobec środowiska oświatowego. Po dyskusji przyjęto, że najważniejsze obszary problemowe to praca ideowo-polityczna wśród pracowników oświaty oraz zwiększenie wpływów w Związku Nauczycielstwa Polskiego ${ }^{3}$. Efektem tej narady było powołanie przez Sekretariat KC PPR w strukturach Wydziału Propagandy KC 27 września 1945 r. Sekcji Oświaty4. Działalność rozpoczęła miesiąc później, a jej pierwszym instruktorem został Jerzy Wesołowski ${ }^{5}$.

Efektem pierwszej narady nauczycieli członków PPR był również okólnik, w którym odniesiono się do pracy wśród nauczycieli. Okólnik ten, jak pisze E. Gorloff, wydany przez KC PPR, został rozesłany do wszystkich Komitetów Wojewódzkich i Powiatowych tej partii. Czytamy w nim, że

Należy również rozpocząć szeroki werbunek nauczycieli do Partii. We wszystkich Komitetach Wojewódzkich wydzielić instruktorów pracy szkolnej i nauczycielskiej. Winni to być nauczyciele-działacze ZNP, instruktorzy ci będą systematycznie zajmować się sprawą szkolnictwa w terenie, obsługiwali komórki nauczycielskie, będą mieć ścisły kontakt z towarzyszami pracującymi w kuratoriach, inspektoratach i zarządach okręgowych ZNP6.

Kolejny okólnik wydany przez Komitet Centralny PPR we wrześniu 1945 r. zawierał stwierdzenia, w których o nauczycielach mówiono, że "zdobycie tego odłamu inteligencji dla klasy robotniczej, dla partii jest konieczne i możliwe" 7 .

Szczególny nacisk kładziono w owym czasie na pozyskiwanie nauczycieli do PPR. Jednakże, wpływy tej partii wśród nauczycielstwa były niewielkie. Przejawiało się to $\mathrm{w}$ tym, iż jakiekolwiek działania zmierzające w tym kierunku nie przynosiły rezultatów. W sprawozdaniach inspektora oświatowego KW PPR w Olsztynie czytamy, że od lipca 1945 do grudnia 1946 r. do PPR początkowo wstąpiło jedynie 37 nauczycieli ${ }^{8}$. Świadczy to o mizerii poczynań komunistów na tym terenie i w tym środowisku, zważywszy, że w październiku 1946 r. w szkołach powszechnych województwa pracowało 1376 nauczycieli ${ }^{9}$.

${ }^{3}$ E. Gorloff, Nauczyciele w przestrzeni działań KW PPR w Gdańsku, [w:] Zaangażowanie? Opór? Gra? Szkic do portretu nauczyciela w latach PRL-u, red. R. Grzybowski, Toruń 2013, s. 87.

4 Protokoły posiedzeń Sekretariatu KC PPR 1945-1946, oprac. A. Kochański, Warszawa 2001, s. 120.

${ }^{5}$ AAN, PPR, sygn. 295/X-19, k.33.

${ }^{6}$ E. Gorloff, Nauczyciele w przestrzeni działań KW PPR, s. 87-88.

7 PPR. Rezolucje, odezwy, instrukcje i okólniki Komitetu Centralnego VIII 1944-XII 1945, oprac. W. Góra, R. Halaba, N. Kołomejczyk, Warszawa 1959, s. 201-202.

${ }^{8}$ APO, zesp. KW PPR, sygn. 1073/103, k.6. Sprawozdanie inspektora oświatowego KW PPR w Olsztynie za miesiąc maj 1947 roku.

${ }_{9}$ APO, zesp. KOS, sygn. 495/4, s. 37. Zestawienie ogólne szkolnictwa powszechnego wg stanu z dn. 10 X 1946 roku. 
Na Warmii i Mazurach próby tworzenia tzw. Sekcji Oświatowych przy KW PPR rozpoczęły się zgodnie z wytycznymi władz centralnych partii w marcu roku 1946. Przeciągały się one jednak w czasie, prawdopodobnie z powodu braku wykwalifikowanych, zaufanych i stojących na odpowiednim poziomie ideowym instruktorów.

Dopiero w kwietniu 1947 r. powołano, mającą czuwać nad realizacją polityki oświatowej partii, pięcioosobową egzekutywę nauczycielską przy KW PPR w Olsztynie ${ }^{10}$. Zorganizowała ona 14 czerwca 1947 r. w Olsztynie pierwszą wojewódzką konferencję nauczycieli PPR-owców, w której wzięli udział przedstawiciele KC PPR, a także partyjni pracownicy Ministerstwa Oświaty. Owocem tego spotkania było wytyczenie głównych kierunków pracy ideowo-wychowawczej w regionie warmińsko-mazurskim ${ }^{11}$. Również w czerwcu 1947 r. wspomniana już egzekutywa wyłoniła swój organ wykonawczy - „trójkę partyjną", która działała do września roku 1947. Jak podkreśla Czesław Lewandowski, istniały one przy Kuratoriach Oświaty we wszystkich województwach. W ich skład wchodzić mieli: delegat Ministerstwa Oświaty i dwóch członków oświatowych władz wojewódzkich. Praktyka pokazała, że jednym z nich był zawsze pracownik komitetu PPR działającego na danym terenie ${ }^{12}$. Jej głównymi zadaniami w tym okresie był dalszy werbunek nowych członków partii i przygotowanie wyborów do władz ZNP13. "Trójki", czyli trzyosobowe Komisje Wyciągania Kadr otrzymały duże uprawnienia. Ich członkowie mogli usuwać niewygodnych urzędników administracji szkolnej oraz decydować o możliwości wykonywania zawodu przez nauczyciela. Posiadały prawo zawieszania dyrektorów, inspektorów w czynnościach służbowych, pozbawiania ich wykonywanej funkcji, a także mianowania na tak uzyskane „wolne” stanowisko zaufanych przedstawicieli władzy ${ }^{14}$. Tenże organ nadzoru w poszukiwaniu obciążających materiałów mógł praktycznie bez ograniczeń korzystać z zasobów wszystkich instytucji państwowych, w tym także z dokumentów Urzędu Bezpieczeństwa Publicznego'15.

10 T. Filipkowski, Oświata na Warmii i Mazurach w latach 1945-60, Warszawa 1978, s. 217.

11 APO, zesp. KW PPR, sygn. 1073/102, k. 4. Konferencja nauczycieli w województwie mazurskim.

12 Cz. Lewandowski, Kierunki tak zwanej ofensywy ideologicznej w polskiej oświacie, nauce $i$ szkołach wyższych w latach 1944-1948, Wrocław 1993, s. 85-86.

${ }_{13}$ APO, zesp. KW PPR, sygn. 1073/103, k.9. Sprawozdanie inspektora oświatowego KW PPR w Olsztynie za czerwiec 1947 roku.

14 A.J. Puliński, Konspiracja i opór. Z dziejów oświaty na Warmii i Mazurach w latach 19451956, Białystok 2007, s. 65.

${ }^{15} \mathrm{Cz}$. Lewandowski, Kierunki tak zwanej ofensywy ideologicznej, s. 85-86. 
Bez wątpienia, owa intensyfikacja działań PPR na terenie województwa olsztyńskiego była związana z ponownym przejęciem resortu oświaty przez członków partii komunistycznej. W tym czasie powołano nowy aparat oświatowy tej partii. Utworzono Wydział Oświaty i Kultury oraz równolegle Komisję Oświaty i Kultury pod przewodnictwem Mariana Spychalskiego $^{16}$. Rozpoczęła ona swoją działalność w 27 lutego 1947 r. Jej celem było stworzenie projektu rezolucji oświatowej. Zadanie to powierzono Kolegium Partyjnemu przy Ministerstwie Oświaty, które wywiązało się z powierzonego zadania i przedstawiło projekt do konsultacji Biuru Politycznemu PPR. Zakładał on, iż w celu zapanowania nad oświatą należy:

1. Za pomocą specjalnych komisji dokonać przeglądu kadr pedagogicznych w celu usunięcia ze stanowisk kierowniczych ludzi o „obcym obliczu” politycznym („elementy reakcyjne") i zastąpić ich („wciągnąć na stanowiska") młodymi nauczycielami o właściwym obliczu ideowym.

2. Selekcję i przegląd kadr dokonać na specjalnie zorganizowanych kursach ideowo-politycznych.

3. Wiedzę ideologiczną i polityczną nauczyciele zdobywają na kursach z zakresu Nauki o Polsce i świecie współczesnym.

4. Nauczycieli tego przedmiotu należy umieszczać na stanowiskach zastępców dyrektorów szkół do spraw społeczno-wychowawczych, podnosząc $\mathrm{w}$ ten sposób ich rolę i znaczenie w środowisku szkolnym.

5. Powołać Wydział Doskonalenia Kadr Pedagogicznych przy Ministerstwie Oświaty, który miałby swoje odpowiedniki w strukturach terenowych oświaty, czyniąc je odpowiedzialnymi za koordynowanie akcji szkolenia ideologicznego nauczycieli ${ }^{17}$.

Pomimo tego, jak pisze W. Chmielewski, że 23 kwietnia 1947 r. BP KC PPR „podjęło decyzję o odrzuceniu przedłożonego przez Kolegium OświatowoKulturalne KC PPR projektu rezolucji oświatowej", a za priorytet uznano, że w szkolnictwie

(...) najważniejsze jest podniesienie poziomu nauczania drogą ofensywy ideologicznej, zmniejszenie ilości dni wolnych i podniesienie dyscypliny 18 , to odrzucenie projektu rezolucji wcale nie oznaczało zaniechania realizacji zawartych w nim treści. Wręcz przeciwnie. Większość z nakreślonych w nim zadań starano się wcielać w życie konsekwentnie, co zresztą stawało się coraz bardziej widoczne w wielu dziedzinach oświaty, a w szczególności w polityce kadrowej i pracy ideowo-wychowawczej19.

16 Tamże, s. 13-15.

17 AAN, zesp. PPR, Oddział VI, sygn. 295/V,3, s. 45-46. Projekt rezolucji oświatowej przygotowanej przez Komisję Oświatowo-Kulturalną w dniu 27 II 1947 roku.

18 W. Chmielewski, Kształcenie nauczycieli w okresie ideologizacji, s. 38.

${ }^{19}$ Tamże. 


\section{Biuro Polityczne zalecało, by}

podjąć ofensywę ideologiczną wśród nauczycielstwa przeciw wrogiej ideologii, jego izolacji i negacji, wciągnięcie do ofensywy ideologicznej wszystkich członków partii, wszystkich członków innych partii bloku i uczciwych demokratów bezpartyjnych przez stałą współpracę w komisjach porozumiewawczych ${ }^{20}$.

PPR już w marcu 1947 r. zapoczątkowała tzw. „czystkę kadrową”. Marian Spychalski żądał wymiany politycznie niepewnych urzędników Ministerstwa Oświaty, jak i nauczycieli nie spełniających wymogów odpowiedniej postawy ideologicznej i politycznej. W ten sposób zainicjowano politykę personalną opierającą się na obsadzaniu stanowisk kierowniczych w administracji oświatowej osobami z punktu widzenia rządzących pewnymi. Ich oblicze ideowe stanowiło główne kryterium przydatności na danym stanowisku. W owym czasie zwolniono z powodów politycznych około 2000 nauczycieli, a uzasadnienie tego stanu rzeczy możemy odszukać w przemówieniu inaugurującym rozpoczęcie roku szkolnego 1947/1948 wygłoszonym przez ministra oświaty, w którym stwierdzał: „Nie ma i nie będzie miejsca w naszej szkole dla wrogów demokratycznego państwa. Wykorzenimy ze szkoły to wszystko, co jest w niej niezgodne z interesami ludowego państwa" 21 .

Pomimo ogólnokrajowej akcji wymiany kadr i działań mających na celu jej upartyjnienie, przyrost nauczycieli będących członkami PPR nie był imponujący, jeżeli mierzyć go w liczbach bezwzględnych. Natomiast, imponująca była dynamika tego przyrostu. Z danych zebranych z terenu całej Polski przez Wydział Personalny Ministerstwa Oświaty wynika, że na początku 1947 r. nauczycieli i pracowników oświaty będących w Partii było jedynie 1300. W połowie tego roku liczba ta zwiększyła się do 5500 osób, by w momencie rozpoczęcia roku szkolnego 1948/1949 osiągnąć 861222.

Również na Warmii i Mazurach znacząco poprawiła się dynamika przyrostu członków partii w oświacie. Jak już wspomniano, w końcówce roku 1946 PPR posiadała w swoich szeregach 37 nauczycieli i pracowników oświaty. W związku z rozpoczęciem procesu obsadzania stanowisk w oświacie członkami partii, sytuacja zaczęła się zmieniać w wyraźny sposób od pierwszych miesięcy 1947 r. Już w maju tego roku w sprawozdaniach Inspektora Oświatowego KW PPR Kazimierza Widlarza zanotowano 100\% przyrost

${ }^{20}$ J. Miąso (red.), Historia wychowania. Wiek XX, Warszawa 1984, s. 333.

${ }^{21}$ U. Pulińska, Doskonalenie zawodowe nauczycieli szkót ogólnoksztatcacych na Warmii i Mazurach w latach 1945-1989, Olsztyn 2005, s. 50.

22 AAN, Oddział VI, sygn. 295/XXI, s. 57. Sprawozdanie Wydziału Personalnego z 28 IX 1948 roku. 
członków PPR wśród oświatowców. Inspektor podaje liczbę 80 osób23. $\mathrm{W}$ drugiej połowie roku ten wzrost był jeszcze większy, ponieważ w środowisku szkolnym w listopadzie 1947 r. odnotowano aż 180 członków PPR24. Interesujące wydaje się, że Widlarz nie uważał, by taka dynamika wzrostu członków partii w oświacie była sukcesem. Wskazywał raczej, iż nie udało się zwerbować więcej członków, ponieważ nie było możliwości przeprowadzenia szerszej akcji agitacyjnej, a nauczyciele wiejscy nie mieli możliwości dotarcia do miast powiatowych, przez co nie mieli kontaktu z KW PPR w Olsztynie. Ta ostatnia przyczyna wydaje się dosyć znacząca, ponieważ w województwie członkowie PPR wśród nauczycielstwa w przeważającej części pracowali na wsi. Wskazywał na miasta i powiaty, gdzie sytuacja pod względem liczebności nauczycieli w szeregach PPR była najgorsza. W ocenie Inspektora Widlarza niekorzystna sytuacja pod tym względem panowała w Morągu, Braniewie, Nidzicy i Kętrzynie ${ }^{25}$.

Kolejne miesiące charakteryzowały się dalszym wzrostem osobowym w tym obszarze. W marcu 1948 r. odnotowano w szeregach PPR 272 nauczycieli26, natomiast w październiku liczba ta zwiększyła się do $371^{27}$. Oznacza to, że dynamika przyrostu została zachowana i wynosiła ponad $100 \%$, licząc rok do roku.

Nieco inaczej przedstawiała się sytuacja w Polskiej Partii Socjalistycznej. Przez wiele miesięcy to $\mathrm{w}$ tej partii zrzeszonych było więcej nauczycieli, niż w PPR. Pierwsze dane dotyczące liczby jej członków pracujących w oświacie we wrześniu 1947 r. mówią o 270 osobach ${ }^{28}$. Od tego momentu liczba członków PPS wśród nauczycieli praktycznie nie wzrosła i w sprawozdaniu z maja 1948 r. podano, że wynosiła 272 osoby ${ }^{29}$.

Intensyfikacja działań oświatowych komórek partyjnych rozpoczęła się niedługo po wyborach do Sejmu Ustawodawczego, które w opinii historyków zostały przez komunistów sfałszowane. Na stanowisko Ministra Oświaty powrócił Stanisław Skrzeszewski i rozpoczęto przygotowania do stworzenia programu "ofensywy ideologicznej". Na marcowym zebraniu

${ }^{23}$ APO. zesp. KW PPR, sygn. 1073/103, k.6.

24 Tamże, k.14. Sprawozdanie Inspektora Oświatowego KW PPR w Olsztynie za miesiąc listopad 1947 roku.

25 Tamże, s. 6-7. Sprawozdanie Inspektora Oświatowego KW PPR w Olsztynie za miesiąc maj 1947 roku.

26 APO, zesp. KW PPR, sygn. 1073/102. Stan liczbowy w województwie olsztyńskim na 1 III 1948 roku.

27 Tamże, k.93. Sprawozdanie Inspektora Oświatowego za październik 1948 roku.

28 APO, zesp. KW PPS, sygn. 1049/9. Sprawozdanie WK PPS w Olsztynie za miesiąc wrzesień 1947 roku.

29 Tamże, Sprawozdanie WK PPS w Olsztynie za miesiąc maj 1948 roku. 
koła nauczycielskiego przy KW PPR w Olsztynie instruktor oświatowy Kazimierz Widlarz przedstawił zebranym główne tezy przemówienia Ministra Oświaty mówiąc, że głównym zadaniem PPR na polu nauczycielskim jest powiększenie kadr, przypuszczenie ofensywy ideologicznej i wychowywanie nauczycieli „biciem i głaskaniem”. Nawiązując do słów ministra podkreślał, że należy wybierać "elementy reakcyjne” wśród nauczycieli i zadawać cios, jednak nie można tego dokonywać bez uzasadnionych podstaw oraz usuwać ludzi "niepowołanych i nieodpowiednich”. Zachęcał „towarzyszy nauczycieli z PPR", by zdobywali wiedzę o Polsce współczesnej, ponieważ ten przedmiot znajdzie się na pierwszym planie $w$ nowych programach szkolnych. Władysław Czapiewicz dodał, że „księża nie powinni wdawać się $\mathrm{w}$ politykę, walczyć $\mathrm{z}$ nimi trzeba tylko $\mathrm{w}$ wypadku, jeśli są reakcjonistami, z religią $\mathrm{w}$ żadnym wypadku" ${ }^{\prime 3}$. Te ostatnie słowa dopisano ołówkiem.

Kolejne zebranie, już w większym gronie, było zebraniem Egzekutywy Nauczycielskiej przy Komitecie Wojewódzkim PPR w Olsztynie. Zebrani omówili najważniejsze sprawy wynikające z przyjętej przez partię taktyki politycznej i ideologicznej. Na porządku dziennym znalazły się więc zmiany personalne, wynikające $\mathrm{z}$ zastosowania klucza partyjnego przy obsadzaniu stanowisk w oświacie i laicyzacja szkoły. Dyskutowano problem wyszukiwania w terenie nauczycieli członków PPR i „wskazywania, na jakie stanowiska można ewentualnie takiego skierować"31. Na spotkaniu tym padły również postulaty organizowania trójek partyjnych $\mathrm{w}$ celu, jak to napisano w protokole:

oddziaływania na masy nauczycielskie przed wyborami do ZNP, by wybory odbyły się w myśl naszej Partii w porozumieniu z bratnią partią PPS. Trójki powiatowe powinny powstać do 15 maja 1947 r. Jednak dotychczas powstały tylko w Giżycku i Ostródzie ${ }^{32}$.

W maju 1947 r. stworzono Sekcję Oświatową w Pasłęku. Jednak nadal w wielu powiatach nie udało się takich sekcji utworzyć. Głównej przyczyny takiego stanu rzeczy upatrywano $\mathrm{w}$ tym, że nauczyciele należący do PPR mieszkali $\mathrm{w}$ miejscowościach zbytnio oddalonych od miast powiatowych. Powiatowi Sekretarze PPR wnioskowali

30 APO, zesp. Kw PPR, sygn 1073/102, k.2. Protokół nr 2 z zebrania Koła członków PPR odbytego w dniu 29 III 47 w obecności 9 członków.

31 APO, zesp. KW PPR, sygn. 1073/102, k.53. Protokół z posiedzenia Egzekutywy Nauczycielskiej przy Komitecie Wojewódzkim PPR w Olsztynie odbytego w dniu 26 IV 1947 roku.

32 Tamże. 
o spowodowanie odgórnie przeniesienia nauczycieli - członków naszej Partii bliżej miast powiatowych, przeprowadzenia zmian na stanowiskach inspektorów szkolnych i kierowników szkól, gdyż stanowiska te obsadzone są przeważnie przez element szkodliwie działający dla naszej Partii33.

W tym czasie rozpoczęło się jawne promowanie członków PPR na różnego rodzaju stanowiska w administracji szkolnej, w celu zwiększenia możliwości oddziaływania na pracowników oświaty ${ }^{34}$. Wśród postulatów kadrowych, mających poprawić sytuację PPR wśród oświatowej kadry kierowniczej i nadzoru pedagogicznego, zdarzały się prośby o poparcie podania jednego z nauczycieli członka PPR, który chciał się przenieść ze wsi do miasta, w którym jest gimnazjum, gdzie mogłyby się kształcić jego dzieci. Według słów Inspektora Oświatowego „towarzysz ten zasługuje na poparcie, gdyż wykazał swą pracą wielką poprawę i wzniósł się na wyższy poziom moralny w stosunku do roku ubiegłego" 35 .

Jak wynika z dokumentów, wszystkie te zmiany, które wiązały się ze stanowiskami inspektorów szkolnych, uzyskały poparcie i obietnicę pozytywnego załatwienia ze strony „wizytatora Ministerstwa Oświaty tow. Lewandowskiego i kuratora szkolnego ob. Koterskiego" 36 . Jednocześnie z tych samych dokumentów wynika, iż Kurator Koterski, jak ujęła to członkini Egzekutywy Kopystyńska,

nie liczy się zupełnie ze zdaniem naszych towarzyszy w Kuratorium (...). Jeżeli zaś chodzi o sprawę nominacji inspektorów szkolnych naszych towarzyszy, to nominacje leżą do tej pory u ob. Kuratora i on nie chce ich wysłać ani też podpisać, tłumacząc się jakąś rozmową ustną w tej sprawie w Ministerstwie Oświaty i że z tymi nominacjami nie należy się spieszyć. Stanowiska swego nie zmienia, mimo kilkakrotnych rozmów w tej sprawie przeprowadzonych przez tow. Kopystyńską ${ }^{37}$.

${ }^{33}$ APO, zesp. KW PPR, sygn. 1073/102, k.7. Sprawozdanie Instruktora Oświatowego KW PPR w Olsztynie za miesiąc maj 1947 roku.

34 Tamże, k.7-8. Sprawozdanie za maj 1947 roku. „W powiecie pasłęckim Kom. Pow. PPR wysunął tow. Chromiaka na stanowisko inspektora szkolnego w uznaniu jego zasług dla Partii oraz pracy i aktywności w życiu społecznym, zaś Towarzysza Filipowicza Antoniego, nauczyciela Szk. Powsz. na stanowisko kierownika Szk. Powsz. w Pasłęku. W powiecie Nidzica, Kom Pow. PPR typuje na kierownika Szk. Powsz. w Nidzicy tow. Miecznikowskiego Leonarda, obecnego kier. Szk. Powsz. w Kozłowie. Tow. Lipińskiego nauczyciela tymcz. we wsi Bartki proszę przenieść bliżej Nidzicy. W powiecie Kętrzyn Kom. Pow. PPR wysuwa tow. Bukowskiego Władysława, kier. Szkoły Powsz. w Srokowie na stanowisko inspektora szkolnego (...) W powiecie Morąg (...) typuje tow. Ferenca Kazimierza, zam. we wsi Glebowo na stanowisko kierownika Szk. Powsz. w Morągu".

35 Tamże, k.8.

${ }^{36}$ APO, zesp. KW PPR 1073/103, k.60. Protokół z posiedzenia Egzekutywy Nauczycielskiej przy KW PPR w Olsztynie odbytego w dniu 7 VII 1947 roku.

${ }^{37}$ Tamże, k.60. 
Kwestie kadrowe, a zwłaszcza rekrutacja nauczycieli do partii, miała także inny wymiar, na który zwrócono uwagę na zebraniach Egzekutywy Nauczycielskiej. Dotyczyło to werbunku do partii nauczycieli z wykorzystaniem lokalnych struktur Urzędu Bezpieczeństwa Publicznego. Jadwiga Królówna, członek Egzekutywy, w jednym ze swoich wystąpień skrytykowała dotychczasowe poczynania „tow. Kopystyńskiej”, która sprawując funkcję tzw. Personalnika przy Kuratorium Oświaty w Olsztynie „wprowadza niepotrzebnie czynnik UBP na teren szkolny, proponuje stanowiska pod warunkiem wpisania się do $\mathrm{PPR}^{\prime \prime 38}$. Ta interesująca sprawa wymaga dalszych studiów, tym razem z wykorzystaniem materiałów WUBP w Olsztynie, zgromadzonych w Instytucie Pamięci Narodowej.

Poza kwestiami tzw. wyciągania kadr, czyli forsowania na stanowiska w oświacie członków PPR, istniało również zjawisko odwrotne, polegające na usuwaniu ze stanowisk niewygodnych politycznie i ideologicznie inspektorów oświaty, kierowników szkół, a nawet poszczególnych nauczycieli. Jednym z takich przykładów, kiedy to członkowie Egzekutywy Nauczycielskiej sugerowali władzom partyjnym, by wpłynęły na władze oświatowe i pozbawiły stanowiska kierownika szkoły był przypadek, jak to napisano „ob. Krzyżaka”, który jako kierownik ośmioklasowej szkoły powszechnej w Iławie został scharakteryzowany jako

były PSL-owiec aresztowany w czasie wyborów za prace antypaństwowe, obecnie bezpartyjny. Należałoby człowieka tego usunąć jak najszybciej ze szkoły, a z kierowniczego stanowiska przede wszystkim, gdyż jest on wrogo usposobiony do współczesnej rzeczywistości i wychowanie dzieci prowadzi w duchu antypaństwowym ${ }^{39}$.

Takich przypadków odnajdujemy o wiele więcej.

W lipcu 1947 r. istniały cztery Sekcje Oświatowe przy Komitetach Powiatowych PPR w Pasłęku, Ostródzie, powiecie olsztyńskim i mieście Olsztynie. Partia miała w swoich szeregach 96 nauczycieli, a przy Kuratorium Okręgu Szkolnego Mazurskiego w Olsztynie pracowały koła nauczycieli członków PPR i PPS, które zwołały wspólne zebranie i na nim doszło do porozumienia oraz nawiązania współpracy. Coraz lepiej układała się współpraca pomiędzy Sekcją Oświatową PPR a Kuratorem Okręgu Szkolnego. Poprawa ta polegała na „uzgadnianiu niektórych spraw z tow. Sekretarzem koła przez

38 APO, zesp. KW PPR, 1073/103, k.71. Protokół z posiedzenia Egzekutywy Nauczycielskiej przy KW PPR w Olsztynie odbytego w dniu 3 XI 1947 roku.

${ }_{39}$ APO, zesp. KW PPR 1073/103, k.18. Sprawozdanie Instruktora Oświatowego KW PPR w Olsztynie z wyborów do Związku Nauczycielstwa Polskiego przeprowadzonych w miesiącu wrześniu 1947 r. w powiatach. 
ob. Kuratora" 40 . Na pochwałę ze strony Instruktora Oświatowego zasłużył również członek egzekutywy Nauczycielskiej przy KW PPR w Olsztynie Czerniakowski, który pracując w Komisji Oświatowej przy Mazurskiej Wojewódzkiej Radzie Narodowej w Olsztynie „wywierał tam duży wpływ i uzgadniał wszystkie sprawy z Sekcją Oświatową KW PPR". Niestety, jak konkludował sprawozdawca, „na Okręgowy Zarząd ZNP Sekcja Oświatowa ma jeszcze słaby wpływ" 41 .

Dane liczbowe przytoczone powyżej świadczą o pewnym sukcesie prowadzonej polityki kadrowej, mimo że w KW PPR w Olsztynie nie uważano tego przyrostu liczbowego członków za zadowalający. Obie partie miały w połowie 1947 r. około 370 członków w szeregach nauczycielstwa (liczba ta w wypadku PPR wzrastała z miesiąca na miesiąc o kilkadziesiąt osób), a to było podstawowym warunkiem do realizacji drugiego, prawdopodobnie najważniejszego w owym czasie celu, a mianowicie opanowania władz ZNP.

Podstawy do takiego działania $\mathrm{w}$ terenie zapewniło podpisanie porozumienia PPR i PPS na szczeblu centralnym. 26 sierpnia 1947 r. w Warszawie zorganizowano konferencję przewodniczących Wydziałów Oświatowych PPR i PPS oraz przedstawicieli centralnego aktywu ZNP należących do obu, jak to wówczas określano, „bratnich partii”. Na konferencji PPR reprezentowali Kierownik Wydziału Oświaty i Kultury Stanisław Trojanowski oraz Eustachy Kuroczko - Przewodniczący Sekcji Nauczycielskiej PPR. Z ramienia PPS występowali Wacław Tułodziecki - Kierownik Wydziału Oświaty i Kultury CKW oraz Stefan Pol - Przewodniczący Centralnej Sekcji Nauczycielskiej PPS. Postanowiono, że

we wszystkich miastach wojewódzkich i powiatowych, tam gdzie istnieją zorganizowane wydziały oświatowe i sekcje nauczycielskie, winny odbyć się w ciągu września wspólne zebrania z udziałem - na stopniu wojewódzkim - przedstawicieli władz centralnych, a na stopniu powiatowym - przedstawicieli władz wojewódzkich obu Partyj. Wezwać sekcje nauczycielskie obu Partyj, aby w wyborach do Zarządów wszystkich komórek Z.N.P. wystąpiły wspólnie w myśl zawartej umowy pomiędzy KC PPR a CKW PPS z dnia 15 III 1947 r. w sprawie wyborów do ZW. Zawodowych. W związku z tym winny w możliwie najkrótszym czasie odbyć się: a) wspólne zebrania Zarządów Sekcyj Nauczycielskich na wszystkich stopniach org. b) wspólne zgromadzenia wszystkich członków Sekcyj Nauczycielskich i działaczy oświatowych $^{42}$.

${ }^{40}$ APO, zesp. KW PPR 1073/103, k.10. Sprawozdanie Instruktora Oświatowego KW PPR za miesiąc lipiec 1947 roku.

${ }^{41}$ Tamże.

42 APO, zesp. KW PPR, sygn. 1073/102, k.22-23. Umowa o współpracy PPR i PPS na odcinku nauczycielskim. 
Dokument Porozumienia zawiera także inne postulaty, jak np.: nakaz uzgadniania wszystkich poczynań na terenie oświatowym i nauczycielskim, potrzebę powołania wspólnych komisji porozumiewawczych Stronnictw Demokratycznych, uzgadnianie akcji wyborczych $\mathrm{w}$ terenie $\mathrm{z}$ pozostałymi Stronnictwami (Stronnictwo Ludowe i Stronnictwo Demokratyczne). Ostatni punkt porozumienia odnosi się do planowanego stworzenia platformy politycznej, której program opracują wspólnie przedstawicielstwa obu partii, na podstawie której prowadzić się będzie

wspólnie zdecydowaną walkę na terenie nauczycielskim i oświatowym z przejawami reakcyjnego kołtuństwa, PSL-em, WIN-em i innymi wrogami Polski Ludowej oraz przejawami sekciarstwa niektórych tow. Tow. z obu Partyj Robotniczych, utrudniającymi realizację jednolitego frontu na terenie oświatowym i nauczycielskim $^{43}$.

Jak można zauważyć po lekturze powyższego dokumentu, władzom PPR i PPS najbardziej zależało na zwiększeniu swoich wpływów w ZNP. Obie partie, zgodnie z wytycznymi wynikającymi z porozumienia, organizowały w tym celu wspólne narady i zjazdy aktywu oświatowego, na których podejmowano decyzje o wspólnym prowadzeniu kampanii wyborczych do władz związku. Na jednym z takich Zjazdów, który odbył się 10 września 1947 r. w gmachu Gimnazjum Męskiego przy ulicy Mickiewicza 6 w Olsztynie, ustalono wspólne stanowisko, z którego wynikało, że

nauczycielstwo obu partii będzie czuwało nad czystością szeregów nauczycielskich, będzie pogłębiało wiedzę ogólną i wiedzę o państwie, będzie dążyć do upowszechniania oświaty na każdym szczeblu kształcenia w myśl postulatów PKWN i dobrych demokratycznych tradycji ZNP, będzie wychowywać młodzież w duchu przywiązania do demokratycznego państwa, będzie repolonizować zgermanizowaną młodzież miejscowego pochodzenia i ich rodziny ${ }^{44}$.

Przemawiający na tym Zjeździe przedstawiciele obu partii podkreślali (w tym delegat Centralnego Komitetu Wykonawczego PPS w Warszawie poseł Polkowski), że należy dążyć do tworzenia porozumiewawczych komisji międzypartyjnych czuwających nad doborem personalnym organizacji zawodowych i samorządowych i tworzyć wspólny front obu partii. Natomiast, Dyrektor Gimnazjum i Liceum w Giżycku Józef Czerniakowski z PPR wysunął postulaty

43 Tamże.

${ }^{44}$ APO, zesp. KW PPR, sygn. 1073/102, k.20. Protokół z Wojewódzkiego Zjazdu aktywistów ZNP, bratnich partii PPR i PPS z dnia 10 września 1947 roku. 
obsadzania składu komisji rewizyjnych, najważniejszych mandatów oraz stanowisk przewodniczących wydziałów pedagogicznych przez członków bratnich partii oraz niedopuszczenie na stanowiska kierownicze elementów reakcyjnych, a wysuwanie jednostek cieszących się mirem i popularnością koleżeństwa ${ }^{45}$.

Na zakończenie zebrani wystosowali do Ministra Oświaty list, w którym zapewnili, że "nauczycielstwo obu bratnich partii będzie czuwało nad czystością szeregów nauczycielskich" 46 .

Kierując się wytycznymi władz centralnych, jak też uzgodnieniami na szczeblu wojewódzkim, PPR przystąpiła do akcji wyborczej do ZNP w powiatach. W Iławie Komitety Powiatowe PPR i PPS wspólnie z inspektorem szkolnym ustaliły listy kandydatów do władz związku. Wśród kandydatów znalazło się czterech członków PPS, jeden z PPR oraz jeden bezpartyjny. $\mathrm{Z}$ punktu widzenia Inspektora Widlarza nie była to lista optymalna, ze względu na jednoosobową reprezentację PPR. Jak sam pisze w sprawozdaniu:

Po naszym przyjeździe i zapoznaniu się z listą kandydatów udało się z trudem zmienić przygotowaną uprzednio listę i doprowadzić do jej przeprowadzenia w głosowaniu jawnym. Ustalony skład pod względem partyjnym przedstawia się następująco - 2 PPR, 2 PPS, 1 SL, 1 bezp. Delegatem ze strony nauczycielstwa, dzięki opozycji delegata Zarządu Głównego ZNP ob. Witkowskiego i zgodzie tow. Frolewicza został członek SL, przewodniczącym wybrano członka PPS $(. . .)^{47}$.

W powiatach Ostróda, Morąg, Braniewo wybory odbywały się bez większych zakłóceń i ingerencji w listy zgłoszone przez, jak to określano „Komisję Matkę". Podkreśla się, że w wyborach negatywną względem PPR rolę próbował odgrywać Witkowski, jednak jego przemówienia, jak to określono w roli ",apologety ob. ob. Wycecha i Maja (...) nie wprowadziło fermentu na Sali, a w rzeczowej krytyce później zostało wyjaśnione" 48 . Nie wszędzie wybory przebiegały bezproblemowo. W Piszu uzgodnionej przez PPR i PPS listy nie chcieli zaaprobować zarówno Prezes Zarządu Powiatowego ZNP, jak i inspektor szkolny oraz delegat Zarządu Głównego ZNP. Widlarz opisuje to tymi słowy:

Niestety ludzie ci nie tylko nie chcieli zgodzić się na przeprowadzenie proponowanych zmian, lecz wręcz otwarcie wypowiedzieli nam walkę. Głównie wyraźnie parł

45 Tamże.

46 Tamże.

47 APO, zesp. KW PPR, sygn. 1073/102, k.18. Sprawozdanie Instruktora Oświatowego KW PPR w Olsztynie z wyborów do Związku Nauczycielstwa Polskiego przeprowadzonych w miesiącu wrześniu 1947 r. w powiatach.

${ }^{48}$ Tamże, k.19. 
do walki ob. delegat Zarządu Głównego Z.N.P., inspektor szkolny i sekretarz inspektoratu szkolnego, wszyscy należący i nie rezygnujący z idei PSL-owskich. Wszelkie namawianie $\mathrm{z}$ naszej strony i propozycje odrzucali $\mathrm{w}$ sposób ordynarny i wysoce obelżywy, co naturalnie przyczyniło się do wytworzenia nerwowego nastroju. Stanowisko swoje motywowali tym, że nie mogą mieć partie polityczne żadnych pretensji do wpływu na Z.N.P. jako na związek zawodowy, że rządy i wpływy PSL-u na tym odcinku są jedynie słuszne ${ }^{49}$.

Atmosfera na sali obrad była tak gorąca, że delegat Zarządu ZNP został z niej wyprowadzony, jak napisano w sprawozdaniu, przez robotników, którzy „weszli na salę, podeszli do delegata i wyprowadzili go z sali obrad $\mathrm{ku}$ zadowoleniu wszystkich zebranych"50. W innych powiatach wybory przebiegały spokojnie, a czasami wręcz w koleżeńskiej atmosferze.

Na podstawie zachowanych danych z 16 na 18 istniejących wówczas oddziałów terenowych ZNP możemy stwierdzić, że obie partie wygrały wybory i do władz terenowych związku wprowadziły 145 osób. W tej liczbie członków PPR było 47, a PPS, które w owym czasie wśród nauczycieli i pracowników administracji szkolnej było liczebnie silniejsze, objęło 55 stanowisk w powiatowych zarządach ZNP51.

Wśród wybranych PPR-owców największą grupę stanowili delegaci z powiatu olsztyńskiego (6 osób) i ostródzkiego (6 osób) oraz biskupieckiego (5 osób). Po jednym mandacie uzyskali przedstawiciele z Braniewa i Pasłęka. Najwięcej mandatów z ramienia PPS przypadło przedstawicielom tej partii z Bartoszyc (7), Morąga (6) i Górowa Iławeckiego (6), najmniej, po jednym, w powiecie szczycieńskim i ostródzkim 52 .

Komitet Wojewódzki PPR nie był jednak zadowolony z osiągniętych wyników, a praca Egzekutywy Nauczycielskiej została oceniona negatywnie, co spowodowało jej przeorganizowanie personalne. Odpowiadający za oświatę II Sekretarz KW PPR na posiedzeniu Egzekutywy w listopadzie 1947 r. zauważył, że nie zdała ona egzaminu w okresie wyborów do ZNP. Niejako w samokrytyce uznał, że sprawy szkolnictwa nie były należycie dostrzegane przez kierownictwo KW, ale sytuacja ta zmieni się. Podkreślił, że Partia posiada „góry nauczycielskie, ale nie mamy wpływów odpowiednich na dołach" 53 .

Innym kierunkiem wyznaczonym do działania była propagandowa akcja ideologiczna, która była prowadzona na wielu kierunkach i miała wy-

49 Tamże, k.29-30.

50 Tamże, k.30.

51 A. Puliński, Konspiracja i opór, s. 68.

52 U. Pulińska, Doskonalenie zawodowe nauczycieli, s. 52.

${ }^{53}$ APO, zesp. KW PPR, sygn. 1073/102, k.69. Protokół z posiedzenia Egzekutywy Nauczycielskiej przy KW PPR w Olsztynie odbytego w dniu 3 XI 1947 roku. 
znaczonych wiele celów. Do jej przeprowadzenia wybrano kursy doskonalenia zawodowego nauczycieli.

Jeszcze w trakcie trwania akcji wyborczej do ZNP postulowano i wprowadzono w życie kilka pomysłów na skuteczne przyciągnięcie na stronę komunistów tzw. „mas nauczycielskich”. W lipcu 1947 r. II Sekretarz KW PPR w Olsztynie goszcząc na posiedzeniu Egzekutywy Nauczycielskiej, zobligował zebranych członków tego ciała do rozwinięcia akcji propagandowej i opracowania takiego planu

uderzeniowego na wszystkie kursy nauczycielskie w naszym terenie i przeprowadzić tam akcję werbunkową. Musimy starać się o podwojenie szeregów nauczycieli PPR-owców. Z tym bowiem stanem nie będziemy mogli skutecznie oddziaływać na przebieg kampanii wyborczej. Lepiej wyrobieni towarzysze powinni poprzez Kuratorium być wysyłani z referatami na te kursy $(. . .)^{54}$.

Pomiędzy 7 lipca a 14 sierpnia w województwie olsztyńskim odbyło się kilka takich kursów, a efekty działania wspomnianych wyżej „lepiej wyrobionych towarzyszy" zostały omówione na sierpniowym posiedzeniu Egzekutywy. Józef Czerniakowski, który miał przeprowadzić akcję propagandowo-werbunkową na kursie dla nauczycieli niewykwalifikowanych w Giżycku, przeprowadzając wykłady z zakresu Nauki o Polsce współczesnej odnotował, że

słuchacze pilnie notowali sobie wykłady, ale konkretnie nie udało mu się zwerbować nikogo do naszej Partii. Element nauczycielski składał się tam z "rozbitków życiowych" pochodzących z pośród drobnomieszczaństwa lub też dawnej burżuazji. Tow. Czerniakowski dochodzi do wniosku, że łatwiej jest przekonać starszych nauczycieli niż młody narybek ${ }^{55}$.

Ta konkluzja wydaje się wielce interesująca, zważywszy, że wśród historyków panuje wręcz odwrotne przekonanie, iż to właśnie młodzi niewykwalifikowani nauczyciele byli bardziej skłonni do pewnych konformistycznych postaw wobec nowej władzy czy też bardziej podatni na komunistyczną propagandę ideologiczną.

Kolejny mówca, którym był Leon Bernacki, „obsłużył” dwa kursy. Jeden dla nauczycieli szkół zawodowych w Ostródzie, zaś drugi - centralny kurs zorganizowany przez ZNP, na którym, jak zaznaczył, w roli prelegentów wystąpili delegaci Ministerstwa Oświaty „którymi byli Czesław Wycech

54 Tamże, k.60. Protokół z posiedzenia Egzekutywy Nauczycielskiej przy KW PPR w Olsztynie odbytego w dniu 7 VII 1947 roku.

55 Tamże, k.62, Protokół z posiedzenia Egzekutywy Nauczycielskiej przy KW PPR w Olsztynie w dniu 14 VIII 1947 roku. 
i ob. Dusza". Kontynuując mówił, iż w trakcie swojego wykładu zauważył wyraźną niechęć słuchaczy, gdy podkreślał „zasługi Polskiej Partii Robotniczej". Próby werbunku obecnych na kursie nauczycieli do Partii nie powiodły się, a postawę polityczną słuchaczy określił jako nijaką, stwierdzając, że nauczycielstwo „nie było ani reakcyjne ani też grawitujące ku którejś partii politycznej" 56 .

Kolejny uczestnik zebrania Marian Palemarczyk doszedł do wniosku, iż cała akcja oddziaływania na nauczycieli poprzez wykłady na kursach była nieprzemyślana, ponieważ by

oddziaływać na nauczyciela trzeba go poznać, trzeba z nim kontaktować się osobiście (...) Należałoby odwiedzać nauczycielstwo na ich placówkach pracy, docierać na najbardziej zapadłe wsie, działać indywidualnie ${ }^{57}$.

Do podobnych wniosków doszedł, zabierający w kolejności głos, Inspektor Oświatowy KW PPR Kazimierz Widlarz, który stwierdził, że

nie mogąc występować jako wykładowca, obrałem drogę działania przez nauczycieli PPR-owców słuchaczy kursu i indywidualne rozmowy. Obsłużyłem kurs w Moragu, Olsztynie i Szczytnie, wszystkie dla nauczycieli niewykwalifikowanych. Rezultatem mojej działalności są cztery konkretne wypadki przystąpienia do naszej Partii ${ }^{58}$.

Podsumowujący zebranie II Sekretarz KW PPR w Olsztynie, jakby pocieszając zebranych i podtrzymując założenia akcji ideologicznej wśród słuchaczy kursów, stwierdził, że

jesteśmy zbyt słabi by skutecznie oddziaływać na zjawiska na odcinku nauczycielskim. Przez akcję przeprowadzoną na kursach mieliśmy zasiać ziarno prawdy wśród mas nauczycielskich i akcja ta była celowa i konieczna (...). Część nauczycielstwa dzięki temu zdobędziemy, część zneutralizujemy, część zachwiejemy (...) Uważam, że obsługa kursów dała nam dużo59.

Radził także zebranym, jak podnosić skuteczność w kontaktach z władzami oświatowymi, by „zdecydowanie więcej rozmawiali z Kuratorem, zbliżyli się do niego, zapraszali do siebie i załatwiali sprawy w sposób towarzyski"60.

Kolejną kwestią wartą omówienia $w$ ramach niniejszego artykułu są sprawy różnego rodzaju szykan, jakich doznawali nauczyciele czy pracow-

56 Tamże, k.62. Wystąpienie Leona Bernackiego.

57 Tamże, k.62. Wystąpienie Mariana Palemarczyka.

58 Tamże, k.62. Wystąpienie Inspektora Oświaty przy KW PPR w Olsztynie Kazimierza Widlarza.

${ }^{59}$ Tamże, k.62-63. Podsumowanie wygłoszone przez II Sekretarza KW PPR w Olsztynie.

${ }^{60}$ Tamże, k.63. 
nicy nadzoru oświatowego, a wynikających z ich przynależności partyjnej do PSL-u lub np. wyznawanej religii.

Egzekutywa Nauczycielska, zwłaszcza w 1948 r., zajmowała się co najmniej kilkoma przypadkami nauczycieli, których chciała usunąć z zajmowanych stanowisk.

W tym celu sporządzano różnego rodzaju charakterystyki nauczycieli. Powstawały one na podstawie doniesień z rozmaitych źródeł. Donosili tajni współpracownicy Urzędu Bezpieczeństwa rozlokowani w szkołach i instytucjach oświatowych, ale także osoby powodowane zwykłą ludzką zawiścią lub inni nauczyciele, którzy robili to z przyczyn ideowych ${ }^{61}$. Pomijając przypadki nauczycieli czy pracowników oświaty zatrzymanych, a następnie skazanych przez Wojskowy Sąd Rejonowy w Olsztynie, które zostały już opisane $\mathrm{w}$ literaturze przedmiotu62, $\mathrm{w}$ dokumentacji partyjnej odnalazłam kilka takich przypadków.

Pierwszy dotyczył wspomnianego już w tym tekście Ludwika Krzyżaka, kierownika Szkoły Podstawowej w Iławie, który został oceniony negatywnie za swoją poprzednią działalność w PSL-u, jak też za to, że zdaniem Inspektora Oświatowego KW PPR w Olsztynie „wykonywał antypaństwową pracę"63.

Inny przypadek dotyczy nauczycielki i pełniącej obowiązki dyrektora Państwowego Gimnazjum i Liceum Komunikacyjnego w Giżycku Jadwigi Sztrauch. Pisano o niej w doniesieniu, że

użyła ona swojego stanowiska do tego, by młodzież trzymać w karbach klerykalizmu i wstecznictwa, występować przeciwko ideologii ZWM poprzez konfiskatę lub korygowanie materiałów do uczniowskiej gazetki ściennej (...), namawiała katechetę gimnazjum do propagowania treści politycznych. W podsumowaniu stwierdzono, że egzekutywa nie rozumie, dlaczego pełni ona nadal funkcję i domaga się usunięcia jej ze stanowiska zajmowanego w szkolnictwie ${ }^{64}$.

W tym samym mieście, ta sama Egzekutywa, w tym samym czasie domagała się usunięcia $\mathrm{z}$ tej samej szkoły ze stanowiska dyrektora Michała Giembickiego. Uznano go za osobę, która "tkwi korzeniami w starym reakcyjnym systemie, pozując na pseudodemokratę" jest „szkodliwa na tym stanowisku", a swoją postawą, jak to ujęto, "oddziaływa złym czarem swego autorytetu na Grono Pedagogiczne 11-letniej szkoły, jak też na grono rodzi-

${ }^{61}$ A. Puliński, Konspiracja i opór, s. 154.

62 A. Puliński, Szykany represje wobec nauczycieli na Warmii i Mazurach w latach 1945-1956, [w:] Zaangażowanie? Opór? Gra?, s. 207-218.

${ }^{63}$ APO, zesp. KW PPR w Olsztynie, sygn. 1073/103, k.19. Sprawozdania instruktorów oświatowych.

64 Tamże, k.43. Wyciąg z Protokołu posiedzenia Egzekutywy Nauczycielskiej Koła PPR w Giżycku z dnia 19 listopada 1948 roku. 
cielskie i młodzież szkolną"65. Zaznaczono, że w ostatnim czasie został usunięty z PPS, a w 1946 r. zgłosił swój akces do PSL-u i stał się orędownikiem tej partii $\mathrm{w}$ powiecie wśród nauczycieli, wykorzystując stanowisko sprawowane w ZNP. Wniosek, jaki postawiono w trakcie posiedzenia sprowadzał się do stwierdzenia, że „obywatel Giembicki winien być izolowany od środowiska na które wywiera zły wpływ" 66 .

Kolejnym przykładem pracownika oświaty, który znalazł się pod pręgierzem nie tylko władz partyjnych, ale również UBP, był działacz PSL i zarazem inspektor szkolny w Szczytnie, który według oświatowych działaczy partyjnych

doprowadził do sytuacji, że prawie całe nauczycielstwo należało do PSL. Po zwycięstwie bloku spowodowal, że nauczycielstwo w masie zapisało się do SL, ale duch pozostał nadal ten sam. Dowodem tego był straszliwy klerykalizm w szkołach, co doprowadziło $\mathrm{w}$ ubiegłym roku szkolnym do rozmaitych starć między uczniami i rodzicami $z$ jednej strony a nauczycielami i księżmi $z$ drugiej strony. Inspektor szkolny oczywiście poparł stronę kleru (...). Spowodował, że przez prowadzenie wygodnej dla siebie polityki kadrowej wśród nauczycielstwa doprowadził do obsadzenia stanowisk kierowniczych i lepszych posad w powiecie nauczycielstwem, które kiedyś należało do PSL. Zajmuje wybitnie negatywne stanowisko wobec Rządu (...) należy zrobić odpowiednie pociągnięcie, aby przeszkodzić rozszerzaniu się dalej wpływów tak szkodliwej jednostki 67 .

Ofiarami zaplanowanych czystek kadrowych w oświacie na terenie województwa olsztyńskiego padło wtedy i później wielu innych nauczycieli oraz pracowników oświaty. Jednym z nich był np. wizytator Kuratorium Szkolnego w Olsztynie Stokowski, którego postanowiono „zdjąć bezwzględnie ze stanowiska i spowodować przeniesienie do innego województwa za działalność na szkodę współczesnej rzeczywistości", której dopuścić miał się poprzez "podtrzymywanie” i faworyzowanie wrogów Polski Ludowej $w$ szkolnictwie ${ }^{68}$. Inną znaną ofiarą, na którą słano różnego rodzaju doniesienia, skutkujące w późniejszym okresie jej zwolnieniem z zajmowanego stanowiska wizytatora przedszkoli, była warmińska poetka ludowa Maria Zientara-Malewska ${ }^{69}$. W dokumentach egzekutywy napisano o niej, że

stanowisko wizytatora przedszkoli w naszym Kuratorium zajmuje w chwili obecnej obywatelka Zientarówna, co do której towarzysze stwierdzają, że jest ona zdecydo-

65 Tamże, k.44.

66 Tamże.

67 APO, zesp. KW PPR, sygn. 1073/103, k.157. Sprawozdanie Instruktora Oświatowego KW PPR w Olsztynie z wyjazdu do Szczytna w dniu 17 IX 1948 roku.

${ }^{68}$ A.J. Puliński, Konspiracja i opór, s. 156.

${ }^{69}$ H. Sawicka, Maria Zientara-Malewska. Zarys monograficzny życia i twórczości, Olsztyn 1981, s. $148-149$. 
waną klerykałką, co ma taki skutek, że w naszych przedszkolach dzieci tylko się modlą, śpiewają pobożne pieśni itd., a o wychowaniu nowego przystosowanego do życia $\mathrm{w}$ obecnej rzeczywistości człowieka nawet nie ma mowy (...) z tych względów należy ją natychmiast zmienić ${ }^{70}$.

W dalszych latach również prowadzono inwigilację nauczycieli i pracowników oświaty, często wykorzystując materiały służb bezpieczeństwa do tworzenia ich charakterystyk. Nasiliła się także ofensywa ideologiczna. Była ona jednak prowadzona przez nowy byt polityczny, jakim była Polska Zjednoczona Partia Robotnicza, powstała w wyniku zjednoczenia PPR i PPS. Jej działalność w dziedzinie oświaty na obszarze Warmii i Mazur wymaga jednak, ze względu na obszerny materiał źródłowy, oddzielnej prezentacji.

Pomimo zakrojonych na dość szeroką skalę działań Sekcji Oświatowej przy KW PPR, a w szczególności bardzo aktywnej postawy członków Egzekutywy Nauczycielskiej w okresie istnienia PPR w województwie olsztyńskim, nie do końca udało się aktywistom partyjnym kontrolującym i nadzorującym obszar oświaty na tym terenie zrealizować stawiane przed nimi cele w dziedzinie indoktrynacji czy werbunku nauczycieli do PPR. Udało się jednak do końca 1948 r. wprowadzić do administracji szkolnej, Związku Nauczycielstwa Polskiego, czy nadzoru pedagogicznego wiele osób związanych z partiami tzw. „obozu demokratycznego”, które w dalszych latach decydowały o kadrach i kształcie oświaty na Warmii i Mazurach.

\section{BIBLIOGRAFIA}

Chmielewski W., Ksztatcenie nauczycieli w okresie ideologizacji szkolnictwa (1944-1956), Warszawa 2006.

Filipkowski T., Oświata na Warmii i Mazurach w latach 1945-60, Warszawa 1978.

Gorloff E., Nauczyciele w przestrzeni działań KW PPR w Gdańsku, [w:] Zaangażowanie? Opór? Gra? Szkic do portretu nauczyciela w latach PRL-u, red. R. Grzybowski, Torun 2013.

Jakubowski J., Polityka oświatowa Polskiej Partii Robotniczej 1944-1948, Warszawa 1975.

Lewandowski Cz., Kierunki tak zwanej ofensywy ideologicznej w polskiej oświacie, nauce i szkołach wyższych w latach 1944-1948, Wrocław 1993.

Miąso J. (red.), Historia wychowania. Wiek XX, Warszawa 1984.

PPR. Rezolucje, odezwy, instrukcje i okólniki Komitetu Centralnego VIII 1944-XII 1945, oprac. W. Góra, R. Halaba, N. Kołomejczyk, Warszawa 1959.

Protokoły posiedzeń Sekretariatu KC PPR 1945-1946, oprac. A. Kochański, Warszawa 2001.

Pulińska U., Doskonalenie zawodowe nauczycieli szkót ogólnokształcących na Warmii i Mazurach w latach 1945-1989, Olsztyn 2005.

70 Tamże. 
Puliński A.J., Konspiracja i opór. Z dziejów oświaty na Warmii i Mazurach w latach 1945-1956, Białystok 2007.

Puliński A., Szykany represje wobec nauczycieli na Warmii i Mazurach w latach 1945-1956, [w:] Zaangażowanie? Opór? Gra? Szkic do portretu nauczyciela w latach PRL-u, red. R. Grzybowski, Torun 2013.

Sawicka H., Maria Zientara-Malewska. Zarys monograficzny życia i twórczości, Olsztyn 1981.

AAN, Oddział VI, sygn. 295/XXI, s. 57. Sprawozdanie Wydziału Personalnego z 28 IX 1948 roku.

AAN, PPR, sygn. 295/X-19, k.33.

AAN, zesp. PPR, Oddział VI, sygn. 295/V, 3, s. 45-46. Projekt rezolucji oświatowej przygotowanej przez Komisję Oświatowo-Kulturalną w dniu 27 II 1947 roku.

APO, zesp. KOS, sygn. 495/4, s. 37. Zestawienie ogólne szkolnictwa powszechnego wg stanu z dn. 10 X 1946 roku.

APO, zesp. KW PPR 1073/103, k.10. Sprawozdanie Instruktora Oświatowego KW PPR za miesiąc lipiec 1947 roku.

APO, zesp. KW PPR 1073/103, k.18. Sprawozdanie Instruktora Oświatowego KW PPR w Olsztynie z wyborów do Związku Nauczycielstwa Polskiego przeprowadzonych w miesiącu wrześniu $1947 \mathrm{r}$. w powiatach.

APO, zesp. KW PPR 1073/103, k.60. Protokół z posiedzenia Egzekutywy Nauczycielskiej przy KW PPR w Olsztynie odbytego w dniu 7 VII 1947 roku.

APO, zesp. KW PPR sygn. 1073/103, k.19. Sprawozdania instruktorów oświatowych.

APO, zesp. KW PPR sygn. 1073/103, k.43. Wyciąg z Protokołu posiedzenia Egzekutywy Nauczycielskiej Koła PPR w Giżycku z dnia 19 listopada 1948 roku.

APO, zesp. KW PPR, 1073/103, k.71. Protokół posiedzenia Egzekutywy Nauczycielskiej przy KW PPR w Olsztynie odbytego w dniu 3 XI 1947 roku.

APO, zesp. KW PPR, sygn. 1073/102, k. 20. Protokół z Wojewódzkiego Zjazdu aktywistów ZNP, bratnich partii PPR i PPS z dnia 10 września 1947 roku.

APO, zesp. KW PPR, sygn. 1073/102, k.18. Sprawozdanie Instruktora Oświatowego KW PPR w Olsztynie z wyborów do Związku Nauczycielstwa Polskiego przeprowadzonych w miesiącu wrześniu $1947 \mathrm{r}$. w powiatach.

APO, zesp. KW PPR, sygn. 1073/102, k.2. Protokół nr 2 z zebrania Koła członków PPR odbytego w dniu 29 III 47 w obecności 9 członków.

APO, zesp. KW PPR, sygn. 1073/102, k.22-23. Umowa o współpracy PPR i PPS na odcinku nauczycielskim.

APO, zesp. KW PPR, sygn. 1073/102, k.4. Konferencja nauczycieli w województwie mazurskim.

APO, zesp. KW PPR, sygn. 1073/102, k.53. Protokół z posiedzenia Egzekutywy Nauczycielskiej przy Komitecie Wojewódzkim PPR w Olsztynie odbytego w dniu 26 IV 1947 roku.

APO, zesp. KW PPR, sygn. 1073/102, k.60. Protokół z posiedzenia Egzekutywy Nauczycielskiej przy KW PPR w Olsztynie odbytego w dniu 7 VII 1947 roku.

APO, zesp. KW PPR, sygn. 1073/102, k.62. Protokół z posiedzenia Egzekutywy Nauczycielskiej przy KW PPR w Olsztynie w dniu 14 VIII 1947 roku.

APO, zesp. KW PPR, sygn. 1073/102, k.62. Wystąpienie Inspektora Oświaty przy KW PPR w Olsztynie Kazimierza Widlarza.

APO, zesp. KW PPR, sygn. 1073/102, k.62. Wystąpienie Leona Bernackiego.

APO, zesp. KW PPR, sygn. 1073/102, k.62. Wystąpienie Mariana Palemarczyka. 
APO, zesp. KW PPR, sygn. 1073/102, k.62-63. Podsumowanie wygłoszone przez II Sekretarza KW PPR w Olsztynie.

APO, zesp. KW PPR, sygn. 1073/102, k.69. Protokół z posiedzenia Egzekutywy Nauczycielskiej przy KW PPR w Olsztynie odbytego w dniu 3 XI 1947 roku.

APO, zesp. KW PPR, sygn. 1073/102, k.7. Sprawozdanie Instruktora Oświatowego KW PPR w Olsztynie za miesiąc maj 1947 roku.

APO, zesp. KW PPR, sygn. 1073/102, k.93. Sprawozdanie Inspektora oświatowego za październik 1948 roku.

APO, zesp. KW PPR, sygn. 1073/102, Stan liczbowy w województwie olsztyńskim na 1 III 1948 roku.

APO, zesp. KW PPR, sygn. 1073/103, k.157. Sprawozdanie Instruktora Oświatowego KW PPR w Olsztynie z wyjazdu do Szczytna w dniu 17 IX 1948 roku.

APO, zesp. KW PPR, sygn. 1073/103, k.6. Sprawozdanie inspektora Oświatowego KW PPR w Olsztynie za miesiąc maj 1947 roku.

APO, zesp. KW PPR, sygn. 1073/103, k.9. Sprawozdanie inspektora Oświatowego KW PPR w Olsztynie za czerwiec 1947 roku.

APO, zesp. KW PPS, sygn. 1049/9. Sprawozdanie WK PPS w Olsztynie za miesiąc wrzesień 1947 roku.

APO, zesp. KW PPS, sygn. 1049/9. Sprawozdanie WK PPS w Olsztynie za miesiąc maj 1948 roku.

APO. zesp. KW PPR, sygn. 1073/103, k.14. Sprawozdanie Inspektora Oświatowego KW PPR w Olsztynie za miesiąc listopad 1947 roku. 